\title{
Literary Creativity and Censorship: Authors in the German Democratic Republic and Their Readers 1949-1989
}

\section{The System of Literary Censorship}

In recent years, much research has gone into the censorship system of literature in the German Democratic Republic (GDR), which was founded in 1949 and existed until 1989. This is a summary of its most salient features.

The GDR perceived itself as a socialist and strictly anti-fascist state on the basis of Marxism-Leninism. It was ruled by the Sozialistische Einheitspartei Deutschlands / SED (Socialist Unity Party of Germany) and was a member of the Warsaw Pact. According to articles 9 and 34 of its constitution, censorship did not exist in that state.

The central committee of the SED, though, determined the guidelines of cultural policy. A state-run institution, the 'Hauptverwaltung Verlage und Buchhandel' (Main Administration of Publishing Houses and Book Trade) served as a central planning unit and provided the directives for publishing houses. Every publishing house needed a state license and had to submit a fiveyear plan in accordance with the directives of the SED. Whenever a publishing house received a manuscript, the lectors became the first censors; two lectors were requested to furnish an opinion. In difficult cases, an additional third opinion was to be obtained. The publishing house then had to submit every text related to a book project to the 'Main Administration' and to apply for a printing permission. The 'Main Administration' thus kept the whole realm of book production under control. In case of politically sensitive texts, the governing body of the SED and the Ministry for State Security might intervene as censors themselves whenever they thought it expedient. It was only those books that had been granted a printing permission which were later available to readers in bookshops.' Talking about issues of censorship in public was a taboo.

1 In the poem "Neues vom Amt" (1977) the 'Hauptverwaltung' was called 'Amt zur Genehmigung von Lebensäußerungen' by author Günter Kunert: “Vom Amt zur Genehmigung von Lebensäußerungen / Kann man sich eine Portion / Atem zuteilen lassen” (Kunert 295). 
The 'Main Administration' also allocated quotas of paper to publishing houses. This meant that it decided about the number of copies printed and about subsequent editions and could also put a stop to the printing of certain books. So it exerted a major influence over the production of books and over the dissemination of literature. In addition it also controlled the assignment of book reviews.

Membership in the writers' association 'Schriftstellerverband der DDR,' which was founded in 1950, was an essential requirement for any author in the GDR who wanted to see his books in print, as only the members were granted the official status as an author. According to its rules, every member of the association had to meet four obligations: to acknowledge "the leading role of the working class and its party in cultural politics," to apply "the method of socialist realism" in his oder her writings, to "resolutely oppose all forms of ideological coexistence" and to fight against "the permeation of literature by all reactionary and revisionist notions. ${ }^{n 2}$

In practice, the criteria for censorship of literature were governed by changing guidelines. A well-known example is the so-called 'Bitterfelder Weg' (Bitterfeld way) in the years after 1961. Authors were then supposed to get acquainted with production facilities and to write about them. The second example is taken from spring 1968, when Soviet troups had occupied Prague and crushed the so-called Prague Spring. In the wake of that event, the SED changed its literary policy. Its new directive consisted in emphasizing the independence of GDR literature and to deny that there was such a thing as a German literature defined by the German language. ${ }^{3}$

\section{Self-Censorship}

In the GDR as in any dictatorship, self-censorship was the most frequent mode of behaviour. Authors bowed to dictates from above which specified the topics they had to write about and the methods they had to use in doing so. Self-censorship offered two advantages: Firstly, it helped to avoid quarrels with censors; secondly, the state rewarded conformism by offering grants and awards and by allocating sufficient paper to publishing houses for large runs of copies. This in turn meant large numbers of copies sold, which secured the author a good income (and reading tours across the country).

2 Cf. Statuten des Schriftstellerverbands der DDR von 1973 (valid until 1989).

3 For that reason the printing of the two volumes of Der deutschsprachige Roman im 20. Jahrhundert was stopped in 1969 last-minute; the book was not put on the market. Zensur in der DDR 75. 
The price for self-censorship, though, was high in the GDR: Authors had to make changes in their manuscripts, they had to come to terms with the censors and, what is more, they had to forgo writing the truth. ${ }^{4}$ There was a dominant feature in GDR censorship: Censors demanded that the authors nod their agreement to deletions. If the authors refused, their books would not go into print. Therefore it is not easy to distinguish clearly between authorial selfcensorship and state censorship (Mix 183).

After the end of the GDR, authors gave accounts of changes which censors had required them to implement. Most of these files have been preserved and we can have a look at an example.

Author Erich Loest was a graduate of the 'Literaturinstitut Johannes $\mathbf{R}$. Becher' (Johannes R. Becher Institue for Literature), a GDR writers' academy located in Leipzig. He had been imprisoned in Bautzen jail, but was granted permission to work as an author after his release. After protracted disputes with state censorship, his novel Es geht seinen Gang oder Mühen in unserer Ebene ('Things are Taking their Course, or: Labours in our Plain') was published in 1977. Its title is a quotation of Bertolt Brecht. Among other things, the novel relates how the state abuses its power on the occasion of an event taken from real life, the violent dispersal of Beatles fans by members of the Volkspolizei (People's Police) in Leipzig. Loest commented on this incident and his novel in a later published documentation of the publication process: "Man kann niemanden mit dem Gummiknüppel überzeugen, dass ein ukrainischesVolkslied edler und fortschrittlicher ist als ein Song der Beatles" (Zensor 9).

Abuse of power was tabooed as a subject in GDR literature. Loest and his lector wrote quite a few letters to each other. After that they had an all-important meeting with the head lector of the publishing house. The result was a compromise: The description of the events was retained, but references to the abuse of power had to be deleted. This is how Loest summed up the debate, which had been going on for four hours: "None of us had shown himself as yielding or even cowardly; both of us had hit each other's eyes with all our force. We felt respect for each other, such as boxers do who had exerted themselves to their utmost."

4 As early as in 1960 author Reiner Kunze expressed this clearly in his short poem "das ende der kunst." An owl is interdicting the capercaillie cock to sing for the sun because the sun was nothing important. The cock stops to sing and is praised highly for this decision: "Du bist ein künstler, / sagte die eule zum auerhahn / Und es war schön finster" (Kunze 51). Censorship of literature here means to stay in the dark and to refrain form light and elucidation.

5 In Loest's manuscript the hero says: "Ich jedenfalls denke so: Macht wird stets ausgeübt von jemandem gegen jemanden. Und der, der Macht ausübt, sollte sich den, der sie zu spüren bekommt, haargenau ansehen." The lector replied that the GDR was not using power against young people who were on the wrong track. Loest describes what happened then: "Erich,' sagte Günther, 'ich sag es Dir klipp und klar: wenn du auf diesem Satz bestehst, reiche ich den 
The struggle for the novel was a sportive challenge: Loest's account of his encounter with censorship shows in an exemplary manner the 'labours of the plain' that had to be dealt with if a book was to be published.

This example also epitomizes the double nature of self-censorship in the GDR: Authors had to delete or mitigate stretches of text containing criticism. This, however, also gave them some latitude to broach important subjects. When Loest's novel caused a major stir, censorship intervened once again and put a halt on a subsequent edition. It was only one and a half years later that another run of 10,000 copies could be printed.

\section{Strategies of Literary Creativity Opposing Censorship}

Authors who made their own personal decisions on their subject and their literary method were running into trouble with censorship. They found specific artistic responses to the way omnipresent censorship impeded their work. I would like to present six types of these responses. Their application helped authors to gain some freedom in their writings.

\section{a) Modernization of Narrative Technique}

In her novella Der geteilte Himmel (The Divided Heaven, 1963), Christa Wolf only partially adheres to official strictures which required authors to portray model figures of a socialist society and to write in the uniform style of 'socialist realism.' Wolf had gained for herself the freedom of an open narrative mode. Her protagonist Rita Seidel wakes up in a hospital and has to deal only with her recollections. Wolf does follow the concept of the 'Bitterfeld Way' by depicting everyday life in a socialist facility (a train factory); however, she goes on to address the deficiencies and hopes prevalent in GDR society. On the other hand, Rita's partner Manfred, a chemist, is an intellectual who leaves the GDR shortly before the building of the Berlin Wall. In Wolf's novella the building of the Berlin wall is an outward sign for the inward alienation of the couple from each other. As was to be expected, official GDR literary criticism of the time looked askance at Wolf's complex narrative technique and Manfred's 'Republikflucht' (desertion from the republic). Still, Wolf was awarded the most prestigious governmental literature prizes for her book (e.g. 1963 Heinrich-Mann-Preis (Heinrich Mann Prize), 1964 Nationalpreis der DDR (National Prize of the

Text nicht ein.' Ich nahm den Kugelschreiber und strich." Zensor 27. Reprint in Loest's autobiography Der Zorn des Schafes: Aus meinem Tagewerk. Künzelsau and Leipzig 1990. 
GDR); in 1964 her novella was made into a film. In the following years, several bans were placed on the book and subsequently lifted again.

Christa Wolf in the novel Nachdenken über Christa T. (The Quest for Christa $T ., 1968)$ even more consistently favours the tenets of literary modernism over those of socialist realism. Her main issues are searching the self and the quest for one's own identity; she also focuses on the problematic nature of the narrative process. In 1968, Wolf justified her open mode of narration thus: "Prose may be used to extend the boundaries of knowledge beyond our own selves." This program went much further than the tentative approaches of other GDR authors. Wolf's lector was so convinced of the novel's quality that he even let passages pass which he should have deleted, such as those referring to the uprising in Hungary. Still, censorship did intervene. It stopped the release of the small print run in the GDR for reasons of personal policy, but later rescinded this order. ${ }^{7}$ Today, the novel is one of the best-known works of GDR literature.

\section{b) The Outsider's Perspective}

A good example for ths type of writing strategy is the novel Der Weg nach Oobladiooh (The Road to Oobliadooh, 1966) by Fritz Rudolf Fries, who then lived in East Berlin. Its main protagonists are Arleq, an interpreter, and Pausch, a failed dentist and excellent pianist. They both love jazz and especially bebop which was considered as decadent Western music in the GDR. The word 'Oobladiooh' is taken from a piece by jazz trumpeter Dizzy Gillespie. Fries' young protagonists just drift through life, do not take anything seriously and again and again escape into fantasy worlds of their own. What for them is just a harmless trip to West Berlin, the state deems the crime of 'Republikflucht.' In this novel we find frequent changes in narrative technique and point of view. The ironic, irreverent book was banned from publication in the GDR as its young anti-heroes are bohemians and thus followers of a life style of Western decadence. In 1966, Fries had the book published in Frankfurt on the Main and on

6 German text: "Prosa kann die Grenzen unseres Wissens über uns selbst weiter hinausschieben." "Lesen und Schreiben" 220.

7 The 'Hauptverwaltung' demanded numerous changes in the text which Wolf rejected. The first edition was printed by a publisher in the Federal Republic. In the GDR the distribution of the book had been stopped. Christa Wolf was asked to resign membership in the GDR Writers' Association. She refused. One month later, after the Writers' Congress of the GDR, her book was published in her country. After the end of the GDR Wolf published a documentation about the process of its publication; Zensur in der DDR $84-89$. 
these grounds lost his academic job in East-Berlin. ${ }^{8}$ It was only in 1989 that the novel was allowed to appear in the GDR.

The outsider's point of view is also crucial to Berlin film director Ulrich Plenzdorf's highly successful play Die neuen Leiden des jungen W. (The New Sorrows of Young W., 1968-1973), whose title alludes to Goethe's epistolary novel Die Leiden des jungen Werther (The Sorrows of Young Werther). The play is based on a film script. After many conflicts with censorship it was published as a book in 1973. Protagonist Edgar Wibeau, 17, has run away from his norrow-minded family home. He is an anti-hero, living in East Berlin in an old arbour. Edgar falls in love with a girl in the neighborhood and wants to take up his studies at an arts college. One day he finds a copy of Goethe's novel Werther and is struck by the insight that he finds his own situation reflected in it. In this play work is no longer the way to self-realization for Edgar but only an obstacle for him. The play by Ulrich Plenzdorf was performed for years on several stages. It made use of teenage language for the first time in GDR literature. ${ }^{9}$ For this innovation, the German translation of James Salinger's novel The Catcher in the Rye, which was published in East Berlin in 1965, served as a model.

\section{c) Bible and Myth as Models}

In 1972, during an interim when censorship was less rigorous, Stefan Heym published his novel Der König David Bericht (The King David Report). Heym had emigrated from Nazi Germany. In 1945 he returned as a member of the so called 'Ritchie Boys' to Germany, and in 1953 he decided to become a GDR-citizen. On the surface, this novel is about a scribe at the court of King Solomon, whose writings are supposed to glorify Solomon's father David, vanquisher of Goliath, but who uncovers some inconvenient truths while doing historical research. The biblical frame, though, is just camouflage. What Heym is really concerned with is 'a veiled account of an author's life in a dictatorship' (Thieme). He criticizes various aspects of life in the GDR: Stalinism, personality cult, propaganda methods and the former head of state Walter Ulbricht.

The plot of Christa Wolf's most ambitious book, the successful novella Kassandra (1983), is taken from the myths focusing on the Trojan War. It deals with King Priam's daughter Cassandra, a seer whose prophecies no one believes in. In two respects, though, the novel ties in with present day issues. First, there is

8 Later it became apparent that Fries had been employed by the State Security as 'Inoffizieller Mitarbeiter' (unofficial collaborator) for some years.

9 A documention of the publishing history is Plenzdorfs 'Neue Leiden des jungen W., 'ed. Peter J. Brenner. 
the build-up of arms in East and West - following the NATO bilateral agreement from 1979 - and the resulting danger of a new war. Censorship demanded e.g. that Wolf should delete the following sentence from her lectures on poetics, which appeared at the same time: 'News from both sides bombs us with the necessity of war preparations, which on both sides are called defence preparations.' Christa Wolf complied and deleted this sentence. ${ }^{10}$ The second connection to present times is her criticism of the patriarchy in the GDR government. Cassandra tries to live a self-determined life in a political system in which only men are part of the authority. Wolf's novella was thus interpreted as a plea for self-determination of women in the GDR (Graves 154-156, 161). Some years later, after the political turn of 1989 in Germany, Wolf once again employed a female protagonist from ancient mythology. Her novel Medea: Stimmen ('Medea: Voices') was published in 1996.

\section{d) Insistence on Socialist Principles}

This literary strategy remains within the boundaries of socialist thinking. It uses its very principles to argue against deviations from it occurring in real life. Here are two examples taken from poetry.

Bertolt Brecht, a writer born in Augsburg and living in the GDR from 1948 on, wrote his poem "Die Lösung" ("The Solution") shortly after June 17, 1953, the day on which the GDR regime brutally crushed the uprising of about 500,000 GDR citizens in East Berlin. Brecht's reaction was sarcasm; in the poem he suggested the government should only disband the people and elect another people. His turning reality upside down revealed who actually held power in the so-called 'Volksdemokratie' (people's democracy) of the GDR. Brecht's poem was banned from publication during his lifetime in the GDR - as well as other critical texts by Brecht from his East Berlin years.

Another striking example is a stanza of the poem "Kern meines Romans" ('The Core of my Novel'), one of the first publications of Uwe Kolbe, today a prominent poet from the former GDR.

10 The novella was published in 1983 both in the DDR and in the Federal Republic of Germany, together with Christa Wolf's lectures about the creation of the text. Kassandra's stance against war turns out to be in vain. The first edition of her novella includes sentences that can be understood as criticizing human rigths violations in the GDR (death for the regime, entrance controls for Troja). Concerning Wolf's case of censorship, see Thomas 20. 
5

Entscheiden Umhaun Chiffrieren Hoffen

Mäkeln Ächten Chemisieren Hoffen Teufeln Intrigieren Graben Einstehen

Gebrauchen Radikalisieren Erfahren Irritieren Singen Erlegen

Ziehen Erregen Randalieren Fluchen Entfernen Tauchen Zerfleddern Enden Durchhalten Infizieren Erwarten

Täuschen Ängstigen Gleichmachen Lärmen Irren Chloroformieren Hoffen Erleben

Revolutionieren Erfinden Verführen Ordnen Lachen Umerziehen Trampeln Isolieren Offenhalten Nacktbaden (qtd. in Zensur in der DDR 185 - 186)

It first appeared in 1981 in an anthology authorized by the state. The censor had simply overlooked what was problematic about this text.

The key to a proper understanding is the third word, 'Chiffrieren' (to encode). Kolbe's poem is an acrostic, which must be recognized as such and decoded. The first letters of all the words add up to the following statement: EUCH MÄCHTIGE Greise ZeRfETZE DIE TÄgliche Revolution (You dotards in power, may the daily revolution tear you to pieces).

What Kolbe articulates here is young people's anger directed against the oligocracy of old men who were in power in the GDR. This poem stands for a rather small body of GDR literature whose messages were encoded. When the authorities belatedly became aware of Kolbe's crass provocation, they barred him from appearing in public for four years.

The poem "Material IV: Der Frieden" by the famous GDR-author Volker Braun provides our last example for this literary strategy.

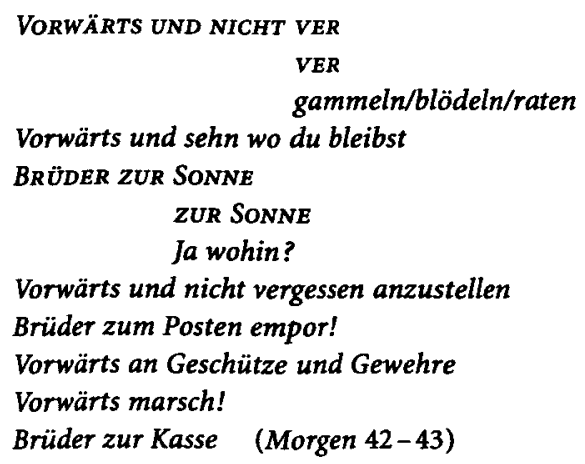

Volker Braun was a convinced, but also a very individual socialist. He had many confrontations with the GDR censors, most of them concerning his HinzeKunze-Roman ('Novel of Hinze and Kunze'). ${ }^{\text {" }}$ But in the end he received a publishing permission anyway.

11 For a documentation, see Mix 156- 198. 
In his poem "Material IV: Der Frieden" ('Material 4: The Peace'), Volker Braun uses citation techniques for political criticism. The texts cited by him are two main texts of the international labour movement, the freedom song "Brüder zur Sonne, zur Freiheit ..." and the solidarity song "Vorwärts und nicht vergessen ..." They are cited as fragments, as if they were nearly forgotten. But Volker Braun criticizes also the myth of the workers' solidarity by writing about inofficial features of GDR-citizens which the state officials denied: individuality, militarism and a fixation on consumption.

e)

\section{Publishing in the GDR in a Private Context}

Another strategy GDR authors chose to publish literature was the usage of a publication channel that did not require a printing permission. From 1982 onwards GDR authors systematically exploited the ruling that small runs of prints were not subject to censorship. In those years they had discovered samizdat literature from the Soviet Union as a model; in addition they also knew examples from the small alternative publishers' scene in Western Germany. The new literary texts shaped by those experiences circulated in the GDR only in small numbers of copies, either as manuscripts or in combination with prints, sometimes as photocopies. In the eighties, they also had the format of a computer printout. An example of these alternative cultural projects relying on a counter-public sphere are the 'Malerbücher' (painters' books) produced in the GDR mainly between 1980 and 1990 . Readings in private homes introduced the audience to these materials.

'Malerbücher' were especially used for shorter genres such as poems, citations and epigrams. Some younger authors who became established only after the end of the GDR, such as Uwe Kolbe, Sascha Anderson and Bernd Wagner, published their first text in this form. But well-known authors of the older generation like Heiner Müller, Elke Erb and Volker Braun also provided texts. The Malerbücher were often published jointly by painters and literary autors as cultural products of an alternative way of life. Famous titles are Ariadnefabrik, Mikado and Bizarre Städte, published from 1982 onwards and only in 30 to 35 copies by self-publishers. They were sold to collectors and connoisseurs by the authors and artists themselves. The new combination of graphics and print escaped the GDR system of censorship. During the last years of the GDR the alternative publications simply ignored the official directions for censorship. The directions did not admit publications about the Berlin Wall, but Volker Braun during the last months of the GDR, in October 1989, published a poem with the political title "Glasnost." These are the last words of the poem (Zickzackbrücke 19): 
Als die Mauer fällt

Seh ich die Mauern in mir

In earlier years Braun would have been sent to prison for utterings like this. But some months later, the end of the year 1989 was also the end of the communist state GDR. In 1991 the Berlin Wall was teared off and the reunification of the two Germanies became a reality. The inner walls of the citizens also started to melt down after 1989.

\section{f) Publishing in the Federal Republic}

Some authors refused to be intimidated during the years of the GDR. They turned to publishers in the Federal Republic with texts which had fallen foul of censorship. As in other countries with strict censorship, prison or camp literature is a typical example - accounts, of the experiences of authors who write about their time in prison or in a camp. In 1978, Jürgen Fuchs published his Vernehmungsprotokolle ('Transcripts of Interrogations) by the GDR state security agency. In 1981, Erich Loest publicized a novel about his years as a political prisoner in Bautzen (Durch die Erde ein Riss; Through the Earth a Rift), and in 1991, Gerhard Artmann found a publisher for a novella about his years in prison in Halle and in Bitterfeld (Zwischenland; The Country Between). After his exile to West Germany Horst Bienek in 1957 published his Traumbuch eines Gefangenen (A Prisoner's Dreambook), which is an account of his experiences in Workuta, a Sovjet penal camp. In 1969, Walter Kempowski wrote an account on his imprisonment in Bautzen (Im Block: Ein Haftbericht; In the Block: An Account on Imprisonment), and in 1989, Ulrich Schacht published his stories Brandenburgische Konzerte (The Brandenburg Concerts); his text partially tells about his prison terms.

Apart from that, there were many other subjects which would never have passed censorship. This, e.g., is the reason why Monika Maron could publish her first novel Flugasche (Flying Ashes) in 1981 only in the Federal Republic. It deals with an environmental disaster caused by the Bitterfeld power plant in SachsenAnhalt.

Publishing in the Federal Republic without permission from GDR authorities entailed further reprisals. Thus, censorship had prevented the printing of Stefan Heym's novel Collin that was first published in 1979 in Munich. Its protagonist himself is an author approved of by the GDR authorities, who, however, on his sickbed starts to write the truth about GDR Stalinism. Heym's novel provoked three official reactions: a high fine for the author for 'currency offences,' a tightening of GDR penal law in this respect and Heym's exclusion from the 
writers' association. Heym gave an account of these incidents in 1988 in his autobiography Nachruf (Obituary).

\section{Readers and 'Secret Readers'}

At the 1981 SED party congress, head of state Erich Honecker called the GDR a 'land of reading.' This was the official self-image propagated by the state. ${ }^{12}$ The GDR indeed offered a great many reading facilities: In 1979, the number of public libraries amounted to 19,000 , which was more than twice as many libraries than in the much larger Federal Republic. When questioned about their reading preferences in $1977,30 \%$ of the citizens said that they favoured "literature by GDR authors' (Teckentrup 256/258). This shows that authors in the GDR were highly respected as public voices. The term 'land of reading,' though, disregards other facts. For even in the GDR, most readers preferred crime novels and popular fiction; even there, reading high class literature was a phenomenon restricted to an elite. What is more, with many citizens, watching TV reduced the time they might have spent on reading.

At a conference in 2007, scholars coined the term 'heimlicher Leser' (clandestine reader, secret reader) for the circumstances of reading in the GDR. ${ }^{13}$ This term refers to a heterogeneous group of citizens who resorted to alternative ways of obtaining books which were not available otherwise. In most cases, they received these books by mail, though customs $\mathrm{x}$-rayed parcels and state security opened 3 to $5 \%$ of all parcels. Such books might also have been obtained as loans or gifts from friends or smuggled from other socialist countries into the GDR or from West Berlin to East Berlin.

Large libraries in the GDR were able to acquire newly released Western books on a regular basis, partly by purchase, partly by book exchange with libraries in the Federal Republic and in other countries. The reading room of the Deutsche Bücherei (German Library) in Leipzig was open to all readers and authors. Author Siegmar Faust even accepted a job as a night watchman in the German Library so that he could be close to these books. In university libraries, though, students had to produce a written endorsement of a lecturer if they wanted to access books on which a ban had been placed.

The most important event of the year, however, was the International Leipzig Book Fair every March (Eckert; Lokatis). Citizens from all over the GDR flocked

12 The highest official in censorship, Klaus Höpcke, cites the phrase in the title of his book Probe auf das Leben: Literatur in einem Leseland.

13 See the Leipzig conference papers: Heimliche Leser in der DDR. Kontrolle und Verbreitung unerlaubter Literatur. Ed. by Siegfried Lokatis. Berlin 2008. 
to Leipzig on this occasion. They read newly released books in the booths of Western publishing houses; they could even take away copies as publishing houses did not mind and simply put a new copy on display. Shorter texts, such as poems and short stories, were copied by hand; even nocturnal theft was quite frequent. This type of 'literary self-appropriation' included catalogues of new books issued by publishing houses, as they gave readers the chance to order and receive new books by mail. Readers also handed on books acquired at the book fair to other people or made photocopies in secret. All these activities to some extent made up for the lack of publicity in their country.

As it is common in a dictatorship, readers also learnt to read between the lines. They were able to supply a context for certain words, to interpret allusions and to draw analogies to the situation in the GDR.

As in other dictatorships, the roman a clef and related literature played an important role in the GDR. Thus, in his historical novel The King David Report, Stefan Heym draws analogies between the biblical King Solomon and the present day situation in the GDR. The protagonist is one of the 'officially accredited teller of stories and legends' (this is GDR officialese); two temple guards are members of the State Security; superiors hush up manipulations after they have come to light. Heym's King Solomon resembles GDR head of state Walter Ulbricht in that he speaks Saxonian vernacular. ${ }^{14}$

In her novella Kassandra (1983), Christa Wolf, too, lays trails which lead straight into the everyday lives of GDR readers. ${ }^{15}$

\section{The 'German-German Literary Exile’ 1977-1989}

The GDR authorities kept certain politically undesirable persons, among them authors, under constant surveillance by day and by night and thus isolated them in their own country. The case of poet Peter Huchel is particularly well-known. In 1962, he was removed from the post of an editor-in-chief of Sinn und Form (Sense and Form), the best GDR literary journal, as he had spoken up for an open concept of literature. Huchel was forced into isolation; from 1968 onwards, all his mail was confiscated. His applications for permission to leave the country were rejected. In 1968, he wrote a poem whose title "Exile" referred to his situation.

14 Another novel by Stefan Heym was banned in the GDR: 5 Tage im Juni (München 1974). Readers in the GDR knew this title referred to the above mentioned upheaval of workers on that day in East Berlin in 1953.

15 A big wall around the city, controls at the border, official language (e. g. 'Sonderbefugnisse für die Kontrollorgane'). Not surprisingly the advisor of the king is in many details similar to Erich Mielke, the hated chief of National Security in the GDR. 


\author{
Am Abend nahen die Freunde, \\ die Schatten der Hügel. \\ Sie treten langsam über die Schwelle, \\ verdunkeln das Salz, \\ verdunkeln das Brot \\ und führen Gespräche mit meinem Schweigen. (11)
}

In 1971, international protest secured him a GDR visa which permitted him to leave for the Federal Republic. The poem "Exile" could only be published in Western Germany.

From 1955 to 1989 , all in all 50 well-known authors had to leave the GDR. ${ }^{16}$ Most of them were exiled to the Federal Republic, a country, in which their native tongue was spoken, but which was alien to them because of an entirely different political and cultural framework. German studies has coined the term 'Deutschdeutsches Literaturexil' (German-German literary exile) for this phenomenon." There has been some discussion if the term 'exile' is appropriate in these cases, but important criteria characterizing the exile experience doubtlessly do apply: the expulsion from one's own country, the move to a 'different world' and the feeling of homelessness experienced there.

The GDR regime had three procedures to force oppositional authors and dissidents into exile, often together with their families.

a) 'Buying-off': Since the 1970s, after protracted negotiations, the regime permitted that the Federal Republic might buy off imprisoned authors. U1richt Schacht and Wolf Deinert, e.g., were thus bought off. For the first time, though, this happened much earlier, in 1957, when Walter Kempowski was bought off after an amnesty.

b) Expatriation: In 1976, song-writer Wolf Biermann gave a concert in Cologne, after an 11 years' stage ban in the GDR. The GDR immediately expatriated him for violation of his civil duties, i. e. he lost his citizenship. For the first time, this led to a protest resolution of well-known GDR authors. Some of these authors, among them Jürgen Fuchs, were also excluded, expatriated and forced to leave.

c) Legal departure: The third procedure was a permission for legal departure. In 1959, it was still possible for Uwe Johnson to leave the GDR by just going from East Berlin to West Berlin. This path was barred after the Berlin Wall had been built in 1961/1962. In 1972, it came as a surprise when Reiner Kunze, who was facing several years' of imprisonment, was permitted to leave the country. An official visa was required for every departure. Authors

16 A list of prominent authors is provided in the appendix.

17 For a discussion, see Deutsch-deutsches Literaturexil. 
who left this way are, among others, Sarah Kirsch, Günter Kunert, Erich Loest, Thomas Brasch, Hans Joachim Schädlich and Monika Maron.

In 1976, a group of autors who had protested against the expatriation of Wolf Biermann were forced to leave the GDR. The poet Sarah Kirsch commented on this in 1979 (53):

Wenn ich in einem Haus bin, das keine Tür hat

Geh ich aus dem Fenster.

Author Bernd Jentzsch did not return to the GDR in 1976 after a stay in the West. In 1978, having lived in exile for two years, Jentzsch wrote the poem "Arioso" about his ambivalent feelings.

Mein Leib und meine sieben Sinne,

Alles frisch und unversehrt.

Das Leben, das ich nun beginne,

Lebt sich grad umgekehrt.

Ich bin der Weggehetzte.

Nicht der erste, nicht der letzte.

Mir ist die Welt ins Herz gesprungen.

Mir, dem großen Lausejungen. (76)

The German-German literary exile considerably affected GDR literature. In conclusion, we can outline four significant consequences.

1. The German-German exile resulted in a GDR literature that was written not only in the GDR but also in the Federal Republic. Authors were allowed to publish their texts with frank thoughts about the situation of the GDR. The SED concept of 1968, which took the state as starting point for defining GDR literature, thus lost its foundation.

2. GDR censorship therefore was no longer in a position to achieve two of its most important objectives. From 1977 onwards, it could neither keep a complete check on the contents of literature, nor could it prevent texts which were undesirable from a political point of view from being published.

3. Exiled GDR authors wrote about subjects which were banned from GDR literature, such as militarism, feminism, abuse of power, political suppression and environmental damage. As a consequence of the success of these books, the GDR had to ease censorship in the 1980 s, so as not to lose even more authors to the West.

4. Some time after the beginning of their German-German exile, former GDR authors increasingly wrote books on different subject matters. Thus, they could avoid the negative image of a 'typical GDR author,' which prevailed in 
the Federal Republic. The economic and political collapse of the GDR late in 1989 put an end to literary censorship and gave rise to democratic structures and freedom for GDR citizens. There was no longer such a thing as a separate GDR literature.

It has now been for 25 years that the literatures of the former two German states have been growing together and merging. Simultaneously, the knowledge about the difficult conditions for production and publishing of literature in the former GDR has been rapidly on the wane in Germany.

\section{Works Cited and Consulted}

Braun, Volker. Langsam knirschender Morgen: Gedichte. Frankfurt a. M. 1987. Print.

一. Die Zickzackbrücke: Ein Abrißkalender. Halle 1992. Print.

Deutsch-deutsches Literaturexil: Schriftstellerinnen und Schriftsteller aus der DDR in der Bundesrepublik. Eds. Walter Schmitz and Jörg Bernig. Dresden 2009. Print.

Eckert, Patricia. "DDR-Leser im Schlaraffenland." Wie im Westen, nur anders: Medien in der DDR. Ed. Stefan Zahlmann. Berlin 2010. 96-111. Print.

Fries, Fritz Rudolf. Der Weg nach Oobladiooh: Roman. Berlin 1966. Print.

Graves, Peter. "Kassandra: Also an Allegory of the GDR's Demise?" Retrospect and Review: Aspects of the Literature of the GDR 1976 - 1990. Ed. Robert Atkins. Amsterdam, Atlanta 1997. 154-163. Print.

Heimliche Leser in der DDR. Kontrolle und Verbreitung unerlaubter Literatur. Ed. Siegfried Lokatis. Berlin 2008. Print.

Heym, Stefan. Collin. München 1979. Print.

- Der König David Bericht. München 1972. Print.

Höpcke, Klaus. Probe auf das Leben: Literatur in einem Leseland. Halle, Leipzig 1982. Print.

Huchel, Peter. Gezählte Tage: Gedichte. Frankfurt a. M. 1985. Print.

Jentzsch, Bernd. Die alte Lust, sich aufzubäumen: Lesebuch. Leipzig 1992. Print.

Kirsch, Sarah. Drachensteigen: 40 neue Gedichte. Ebenhausen bei München 1979. Print.

Kolbe, Uwe. "Kern meines Romans.” Bestandsaufnahme 2: Debütanten 1976-1980. Ed. Brigitte Böttcher. Halle, Leipzig 1981. Print.

Kunert, Günter. Die Schreie der Fledermäuse: Geschichten, Gedichte, Aufsätze. München 1979. Print.

Kunze, Reiner. Gedichte. Frankfurt a. M. 2001. Print.

Loest, Erich. Es geht seinen Gang oder Mühen in unserer Ebene: Roman. Halle 1977. Print.

-. Der vierte Zensor: Vom Entstehen und Sterben eines Romans in der DDR. Köln: Edition Deutschland-Archiv 1984. Print.

Lokatis, Siegfried. "Die Hauptverwaltung des Leselandes." Leseland DDR. Special nr. of Das Parlament, suppl. Aus Politik und Zeitgeschichte 11 (2009). 23 -31. Print.

Maron, Monika. Flugasche: Roman. Frankfurt a. M. 1981. Print. 
Mix, York-Gothart. "DDR-Literatur und Zensur in der Honecker-Ära (1971 - 1989), Teil I." Internationales Archiv für Sozialgeschichte der Literatur 23 (1998). 156-198. Print. Plenzdorf, Ulrich. Die neuen Leiden des jungen W. Rostock 1973. Print.

Plenzdorfs 'Neue Leiden des jungen W.' Ed. Peter J. Brenner. Frankfurt a. M. 1982. Print. Teckentrup, Konrad H. "Die Erforschung des Buches in der Deutschen Demokratischen Republik." Buch und Lesen International. Berichte und Analysen zum Buchmarkt und zur Buchmarkt-Forschung. Eds. Konrad H. Teckentrup and Petra F. Dorsch. Gütersloh 1981. 256-275. Print.

Thieme, Tom. "Mehr als ein Weltliterat: Die Sonderrolle Stefan Heyms in der Ära Honecker.” Deutschland-Archiv 11/12 (2011): n.pag. Web. 15 Feb. 2014.

Thomas, Rüdiger. "Lebensmuster - Wege zu Christa Wolf." Das Parlament, suppl. Aus Politik und Zeitsgeschichte 11 (2009): 15 -23. Print.

Wolf, Christa. Der geteilte Himmel: Erzählung. Halle 1963. Print.

-. Kassandra: Vier Vorlesungen. Eine Erzählung. Berlin, Weimar 1983. Print.

-. Lesen und Schreiben: Aufsätze und Prosastücke. Darmstadt 1972.

-. Nachdenken über Christa T. Halle 1968. Print.

Zensur in der DDR. Geschichte, Praxis und 'Ästhetik' der Behinderung von Literatur. Ausstellungsbuch. Eds. Ernest Wichner and Herbert Wiesner. Berlin 1991. Print.

\section{Appendix: A selection of authors who left the GDR}

1955 Horst Bienek (after amnesty from prison)

1957 Walter Kempowski (after amnesty from prison), Gerhard Zwerenz

1959 Uwe Johnson, Heinar Kipphardt (not returned from Düsseldorf)

1965 Manfred Bieler (exiled from Prag to the federal Republic), Hartmut Lange (not returned from Yugoslavia)

1966 Helga M. Nowak (expatriation)

1968 Udo Steinke (not returned from business trip)

1971 Peter Huchel (visa)

1973 Klaus Kordon (bought off)

1974 Wolf Deinert (bought off), Christa Reinig, Gerald K. Zschorsch (bought off)

1976 Wolf Biermann (expatriation), Thomas Brasch (visa), Jürgen Fuchs (expatriation), Siegmar Faust (expatriation), Bernd Jentzsch (not returned from business trip to Switzerland), Sarah Kirsch (visa), Ulrich Schacht (bought off), Hans-Joachim Schädlich (visa), Einar Schleef (not returned from Vienna)

1977 Jurek Becker (visa), Jürgen Fuchs (expatriation), Reiner Kunze (expatriation), Michael Sallmann (expatriation)

1978 Christine Wolter (visa)

1979 Joachim Seyppel (visa), Günter Kunert (visa), Klaus Poche (visa) 
1980 Kurt Bartsch (visa), Utz Rachowski (expatriation), Klaus Schlesinger (visa), Stefan Schütz (visa), Bettina Wegner (visa)

1981 Karl-Heinz Jakobs (visa), Erich Loest (visa), Frank-Wolf Matthies (visa)

1982 Dieter Eue (expatriation)

1983 Wolfgang Hegewald (visa)

1984 Barbara Honigmann (visa), Katja Lange-Müller (visa), Karl Hermann Roehricht (expatriation), Cornelia Schleime (visa)

1985 Gerhard Artmann, Wolfgang Hilbig (visa), Bernd Wagner (expatriation)

1986 Sascha Anderson (visa), Monika Maron (visa)

1987 Uwe Kolbe (visa)

1988 Freya Klier (expatriation), Stephan Krawczyk (expatriation), Irina Liebmann (visa) 